\title{
Antibacterial Activity and Synergism of the Hybrid Antimicrobial Peptide, CAMA-syn
}

\author{
Ki-Woong Jeong, Soyoung Shin, Jin-Kỵoung Kim, and Yangmee Kim*
}

\author{
Department of Bioscience and Biotechnologv, Bio. Lolectlar Informatics Center, Konkuk Universitv, Seoul 143-701, Korea \\ E-mail: rmkimiákonkukackr \\ Received June 22, 2009, Accepted June 26, 2009
}

\begin{abstract}
A 20-residue hybrid peptide CA(1-8)-MA(1-12) (CAMA) incorporating residues 1-8 of cecropin A (CA) and residues 1-12 of magainin 2 (MA) has high antimicrobial activity without toxicity. To investigate the effects of the total positive charges of CAMA on the antibacterial activity and toxicity, a hybrid peptide analogue (CAMA-syn) was designed with substitutions of $I l \mathrm{e}^{10}$ and Ser ${ }^{16}$ with Lys. According to CD spectra, structure of CAMA-syn with increase of cationicity was very similar to that of CAMA in DPC micelle. CAMA-syn showed antimicrobial activity similar with CAMA while CAMA-sy'n has no hemoly tic activity and much lower cytotoxicity against RAW 264.7 macrophage cells than CAMA. Also, CAMA and CAMA-syn significantly inhibited NO production by LPSstimulated RAW264.7 macrophage at $10.0 \sim 20.0 \mu \mathrm{M}$. CAMA-syn displayed salt resistance on antimicrobial activity against Escherichia coli at the phy siological concentrations of $\mathrm{CaCl}_{2}$ and $\mathrm{MgCl}_{2}$. The combination studies of peptides and antibiotics showed that CAMA-syn has synergistic effects with synthetic compound and flavonoid against Enterococars faecalis and VREF. CAMA-syn can be a good candidate for the development of new antibiotics with potent antibacterial and sy'nergistic activity but without cy totoxicity.
\end{abstract}

Key Wonds: CAMA-syn, Antibacterial activity. Flavonoid. Antibiotics. Synergism

\section{Introduction}

Antimicrobial peptides have been found in a variety of sources, including mammals. amphibians. and insects. ${ }^{1-5}$ These natural antimicrobial peptides are known to play important roles in the host defense system and innate immunity. ${ }^{1-5}$ Recently. the rapid emergence of antibiotic resistant-bacterial and fungal strains has resulted in considerable interest in using natural antimicrobial peptides as therapeutic agents. ${ }^{6.16} \mathrm{Cecro}-$ pin A (CA). a cationic 37-amino acid antimicrobial peptide was isolated from the hemolymph of the giant silk moth. Hyalophora cecropia ${ }^{3,8,811,12}$ Magainin 2 (MA). a 23-amino acid antimicrobial peptide. was discovered in the skin of the African clawed frog. Tenopus laevis ${ }^{4.13} \mathrm{CA}$ and MA display powerful lytic activity against Gram-positive and Gram-negative bacteria, but have no cy totoxic effects against human erythrocytes and other eukary otic cells. Melittin (ME), a 26 amino acid peptide that is the major component of the venom of honey bee Apis mellifera, has powerful antibacterial and antifungal activities. and it possesses high hemolytic activity. ${ }^{1+16}$ These cationic antimicrobial peptides are thought to act by forming an amphipathic $\alpha$-helix. which leads to subsequent membrane disnuption by' means of ion channel/pore formation and eventually cell death. ${ }^{6}$

In the course of systematic studies aimed at finding antibiotic peptides with improved antibacterial activity and no hemolytic effect. a series of hybrid peptides have been developed ${ }^{1+18}$ For example. cecropin A-magainin 2 (CAMA) hybrid peptides comprising the $\mathrm{N}$-terminal amphipathic basic region of $\mathrm{CA}$ and the $\mathrm{N}$-terminal hydrophobic region of MA and cecropin A-melittin (CAME) lybrid peptides comprising the $\mathrm{N}$-terminal amphipathic basic region of $\mathrm{CA}$ and the $\mathrm{N}$-terminal hydrophobic region of melittin (ME) displayed high antibacterial and antitumor activities. but showed no hemolytic activity at $100 \mu \mathrm{g} / \mathrm{mL}$. $^{1+210}$

Recent reports have demonstrated that in vitro interaction of some cationic peptides with several clinically used antibiotics against several clinical isolates of Gram-positive and Gramnegative bacteria. ${ }^{3-2+}$ The use of combinations of antimicrobials is conmon in the clinical setting and expands the spectrum of organism that can be targeted. prevents the emergence of resistant organism. decreases toxicity by allowing lower doses of both agents and can result in sy nergistic inhibition. ${ }^{25}$

In this study we sy'nthesized the hybrid peptide analogue CAMA-syn with substitutions of Ile ${ }^{15}$ and Ser ${ }^{16}$ with Lys in CAMA resulting in increase of total positive charge. We evaluated their antibacterial activities as well as toxicities to human erythrocytes. We then investigated their ability to act synergistically in combination with some antimicrobial flavonoids and synthetic compounds.

\section{Methods}

Peptide synthesis. All peptides specified in Table 1 were prepared by' solid-phase synthesis using Fmoc chemistry. Peptides were purified by reversed-phase preparative high-performance liquid chromatography on a $\mathrm{C}_{18}$ column $(20 \times 250$ $\mathrm{mm}$ : Shim-pack) using a gradient of $20 \%$ to $50 \%$ acetonitrile in $\mathrm{H}_{2} \mathrm{O}$ with $0.1 \%$ TFA delivered over $30 \mathrm{~min}^{26}$ Analytical high-performance liquid chromatography with an ODS column $(4.6 \times 250 \mathrm{mum}$ : Shim-pack) revealed that purified peptides were more than $95 \%$ homogeneous (data not shown). The peptides also had the correct atomic masses as determined by matrix-assisted laser desorption/ionization time-of-flight mass spectrometry. 
Table 1. Amino acid sequences of CAMA and CAMA-syn and their hydrophilicities

\begin{tabular}{llcrc}
\hline Peptide & \multicolumn{1}{c}{ Sequences } & M.W. & Net charge $^{a}$ & Hydrophilicity $^{b}$ \\
\hline CAMA & KWKLFKKIGIGKFLHSAKKF-NH 2 & 2405.02 & 8.1 & 0.1 \\
CAMA-syn & KWKLFKKIGKGKFLHKAKKF-NH & 2459.56 & 10.1 & 0.5 \\
\hline
\end{tabular}

"Net charge was calculated using sum of each of the amino acid charge at $\mathrm{pH} 7.0$. Hydrophilicity is the total hydrophilicity (sum of all residue hydrophilicity indices) divided by the number of residues according to the Hopp \& Wood index.

Bacterial strains. Escherichia coli KCTC 1682. Pseudomonas aeruginosa KCTC 1637. Bacilhts subtilis KCTC 3068. Staphylococcus aurets KCTC $162 \mathrm{I}$ and Enterococcus faecalis KCTC 2011 were purchased from the Korean Collection for Tyye Cultures. Korea Research Institute of Bioscience \& Biotechnology (Taejon, Korea). Methicillin-resistant $S$. aureus (MRSA) (CCARM 3126) was obtained from the Culture Collection of Antibiotic-Resistant Microbes (CCARM) at Seoul Women's University in Korea and the clinical isolates of vancomycin-resistant $E$. faecalis (VREF) was supplied from the Research Institute of Bacterial Resistance Yonsei University College of Medicine (Seoul. Korea)

Hemolytic activity. Hemolytic activity of the peptides was tested against human red blood cells (h-RBC). Fresh h-RBCs were washed three times with phosphate-buffered saline PBS (PBS: $35 \mathrm{mM}$ phosphate buffer containing $150 \mathrm{mM} \mathrm{NaCl}$. pH 7.4) by centrifugation for $10 \mathrm{~min}$ at $1000 \mathrm{~g}$ and resuspended in PBS. The peptide solutions were then added to $50 \mathrm{~mL}$ of hRBC in PBS to give a final volume of $100 \mathrm{~mL}$ and a final erythrocyte concentration of $4 \%$. $v / v$. The resulting suspension was incubated with agitation for $1 \mathrm{~h}$ at $37^{\circ} \mathrm{C}$. The samples were centrifuged at $1000 \mathrm{~g}$ for $5 \mathrm{~min}$. Release of hemoglobin was monitored by measuring the absorbance of the supernatant at $405 \mathrm{~nm}$. Controls for no hemoly sis (blank) and 100\% hemolysis consisted of human red blood cells suspended in PBS and $0.1 \%$ Triton X-100, respectively. The percent hemolysis was calculated using the following equation:

$$
\begin{aligned}
& \text { Hemolysis }(\%)= \\
& \text { [(OD }
\end{aligned}
$$

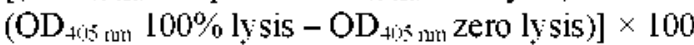

Mammalian cell culture and cytotoxic activity. The mouse macrophage RAW264.7 cells were obtained from the Korea Research Institute of Chemical Technology (KRICT) (Daejon, Korea). Cells were cultured in RPMI 1640 supplemented with $10 \%$ fetal bovine serum and antibiotic-antimyotic solution ( 100 units $/ \mathrm{mL}$ penicillin. $100 \mathrm{~g} / \mathrm{mL}$ streptomy cin and $25 \mathrm{~g}$ amphotericin $\mathrm{B}$ ) in $5 \% \mathrm{CO}_{2}$ at $37^{\circ} \mathrm{C} .=$ Cultures were passed every 3 to 5 days. and cells were detached by brief trypsin treatment. and visualized with an inverted microscope. Cytotoxicity of peptides against RAW264.7 cells was determined using the MTT assay as reported previously. ${ }^{28}$ with minor modifications. Cells were seeded on 96-well microplates at a density of $2 \times 10^{4}$ cells/well in $150 \mathrm{~mL}$ RPMI 1640 containing $10 \%$ fetal bovine senum. Plates were incubated for 24 h at $37{ }^{\circ} \mathrm{C}$ in $5 \% \mathrm{CO}_{2}$. Peptide solutions $(20 \mu \mathrm{L}$ ) (serial 2-fold dilutions inRPMI $6+0$ ) were added. and the plates further incubated for 1 day. Wells containing cells without peptides served as controls. Subse- quently, $20 \mathrm{~mL}$ MTT solution $(5 \mathrm{mg} / \mathrm{mL}$ ) was added in each well, and the plates were incubated for a further $4 \mathrm{~h}$ at $37^{\circ} \mathrm{C}$. Precipitated MTT formazan was dissolved in $40 \mathrm{~mL}$ of $20 \%$ (w/v) SDS containing $0.01 \mathrm{M} \mathrm{HCl}$ for $2 \mathrm{~h}$. Absorbance at 570 $\mathrm{nm}$ was measured using a microplate ELISA reader (Molecular Devices. Sunnyvale. CA). Cell survival was expressed as a percentage of the ratio of $A_{5: c}$ of cells treated with peptide to that of cells only.

Quantitation of nitrite production in LPS-stimulated RAW 264.7 cells. RAW264. 7 cell suspensions were stored at room temperature and used within 6 hours. Nitrite accumulation in culture media was used as an indicator of NO production. 9 Cells were plated at a density of $5 \times 10^{5}$ cells $/ \mathrm{mL}$ in $96-w e l l$ culture plates. and stimulated with LPS ( $20 \mathrm{ng} / \mathrm{mL}$ ) from $E$. coll Olll:B4 (Sigma) in the presence or absence of peptides for 24 hour. Isolated supenatant fractions were nuxed with an equal volume of Griess reagent ( $1 \%$ sulfanilamide. $0.1 \%$ naphthylethy lenedianine dihydrochloride. $2 \%$ phosphoric acid) and incubated at room temperature for 10 minutes. Nitrite production was measured by absorbance at $540 \mathrm{~nm}$. and nitrite concentrations were determined using a standard curve generated with $\mathrm{NaNO}_{2}$

CD analysis. CD experiments were performed using a J-810 spectropolarimeter (Jasco. Tokyo. Japan) with a l-1mm path length cell. The CD spectra of the peptides at $100 \mu \mathrm{M}$ were recorded at $25^{\circ} \mathrm{C}$ in 0.1 -nm intervals from 190 to 250 $\mathrm{nm}$. To investigate the conformational changes induced by DPC nicelles were added to the peptides. For each spectrum. the data from 10 scans was averaged and smoothed using J810 spectrometer. $C D$ data were expressed as the mean residue ellipticity $[\theta]$ in deg $\mathrm{cm}^{2} \cdot \mathrm{dmol}^{-1}$.

Salt resistance test and synergistic effect. The antimicrobial activities of peptides. flavonoids. and synthetic compound were tested against selected organisms. including three Grampositive. three Grant-negative and antibiotics resistant bacteria, as described previously ${ }^{3 i}$ The salt resistance test was also performed under the fixed concentrations of $\mathrm{NaCl}, \mathrm{CaCl}_{2}$ or $\mathrm{MgCl}_{2}$.

The syynergistic effects between each peptide and antimicrobial agents against $E$. faecalis and VREF were investigated by the combination assay. Two-fold serial dilutions of flavonoids were tested in the presence of a constant amount of peptide. equal to one-quarter and one-eighth of the MIC value of the peptides. Synergy was defined as occurring when the MIC of each of the drugs in the combination was one-quarter or less of the MIC of each drug alone. ${ }^{31}$ To evaluate the effect of the combinations, the fractional inhibitory concentration (FIC) was calculated for each antibiotic in each combination. ${ }^{32}$ The following formula were used to calculate the FIC index: FIC of dnig $\mathrm{A}=$ MIC of drug A in combination/MIC of drug A alone. FIC of 
Table 2. Antinicrobial activity of CAMA and CAMA-Syn

\begin{tabular}{|c|c|c|c|c|c|c|c|}
\hline \multirow{3}{*}{ Peptide } & \multicolumn{7}{|c|}{ MIC $(\mu \mathrm{M})$} \\
\hline & \multicolumn{5}{|c|}{ Standard bacterial strair } & \multicolumn{2}{|c|}{ Antibiotic-resistant bacterial strain } \\
\hline & E. coli & P. aenginosa & S. attrets & B. subtilis & E. faecalis & MRSA & VREF \\
\hline CAMA & 1 & 2 & 4 & 4 & 8 & 8 & 32 \\
\hline CAMA-syn & 2 & 2 & 4 & 4 & 16 & 4 & 8 \\
\hline Melittin & 2 & 4 & 2 & 2 & 8 & 2 & 2 \\
\hline
\end{tabular}

drug $\mathrm{B}=\mathrm{MIC}$ of drug $\mathrm{B}$ in combination $\mathrm{MIC}$ of drug $\mathrm{B}$ alone, and FIC index = FIC of dnig A + FIC of drug B. Sy nergy was defined as an FIC index $\leq 0.5$. Indifference was defined as an FIC index of $>0.5$ but of $\leq+$. Antagonism was defined as an FIC index of $>4 .^{3 ?}$

\section{Results and Discussion}

Generally. a number of parameters. including amphipathic feature, net positive charge, $\alpha$-helicity. and overall hydrophobicity have been shown to modulate the antibiotic activity of $\alpha$-helical amphipathic antimicrobial peptides. ${ }^{20}$. 1 In order to investigate the effects of cationicity on antibacterial activity. salt resistance and toxicity. CAMA-Sy'n in which the Ile ${ }^{10}$ and Ser ${ }^{16}$ sequence of CAMA were substituted with Lys was synthesized to increase net positive charge. As listed in Table 1. CAMA has net positive charge of +8.1 and a hydrophilicity of 0.1 . as calculated by the Hopp and Woods index 35 while CAMAsyn has a net charge of +10.1 and a hydrophilicity of 0.5 . Therefore. CAMA-syn is more highly positively charged.

Antimicrobial activities of the CAMA and CAMA-ș'n were examined against a representative set of bacterial strains. including 2 gram-negative species ( $E$. coli and $P$. aeriginosa) and 3 gram-positive species ( $B$. subtilis. E. faecalis and $S$. atreus). and 2 antibiotic-resistant bacterial strains (Methicillin-resistant $S$ aurets (CCARM 3126), and Vancomycin-resistant $E$. faecalis (clinical isolates)). As shown in Table 2. substitution of the Ile ${ }^{10}$ and Ser ${ }^{16}$ with Ly's led to small decrease of antimicrobial activity against standard bacterial strain while CAMA-syn has 2 to 4-fold increase of antibacterial activity against MRSA and VREF compared to CAMA.

Table 3. Effects of increasing concentrations of $\mathrm{NaCl}, \mathrm{CaCl}$ and $\mathrm{MgCl}_{2}$ on MICs of peptides against $E$. coli and $S$ aurens

\begin{tabular}{|c|c|c|c|c|c|}
\hline \multirow{3}{*}{ salt } & \multicolumn{5}{|c|}{ MIC $(\lfloor M)$} \\
\hline & \multirow{2}{*}{$\begin{array}{l}\text { Concn } \\
(\mathrm{mM})\end{array}$} & \multicolumn{2}{|c|}{ E. coli } & \multicolumn{2}{|c|}{ S. aureus } \\
\hline & & CAMA & CAMA-syn & CAMA & CAMA-syn \\
\hline none & & 1 & 2 & 4 & 4 \\
\hline \multirow[t]{3}{*}{$\mathrm{NaCl}$} & 100 & 1 & 2 & 8 & 8 \\
\hline & 150 & 4 & 8 & 16 & 16 \\
\hline & 200 & 8 & 16 & 32 & 32 \\
\hline \multirow[t]{3}{*}{$\mathrm{CaCl}_{\text {: }}$} & 1 & 1 & 2 & $n d^{a}$ & nd \\
\hline & 3 & 2 & 4 & nnd & nnd \\
\hline & 5 & 2 & 8 & nd & nd \\
\hline \multirow[t]{3}{*}{$\mathrm{MgCl}_{2}$} & l & 1 & 2 & nid & nid \\
\hline & 3 & 1 & 2 & nd & nd \\
\hline & 5 & 1 & 2 & nnd & nnd \\
\hline
\end{tabular}

"nd : not determined.
The $\mathrm{NaCl}$ concentration of $120 \mathrm{mM}$ has been reported to be present in the env ironment of the epithelial cells of CF patients. ${ }^{36}$ The one of major pathogen of CF patients was known to be $S$. aureus: Also. interactions between cationic peptide and lipopolysaccharide surface consisting of the outer membrane of Grant-negative bacteria are inhibited by ligh concentrations of divalent cations. such as calcium and magnesium. ${ }^{3 *}$ For these reasons, the MICs of CAMA and CAMA-syn for $E$. colt and $S$. aureus were determined in presence of $\mathrm{NaCl} . \mathrm{CaCl}_{2}$. and $\mathrm{MgCl}_{2}$, respectively. Although +-fold increase in the MCS of CAMA and CAMA-syn in the presence of $150 \mathrm{mM} \mathrm{NaCl}$ and $5 \mathrm{mM} \mathrm{CaCl}_{2}$, there is no significant increase in the MICs of these peptides against $E$. coli under $1 \mathrm{mM} \mathrm{CaCl} 2$ or $5 \mathrm{mM}$ $\mathrm{MgCl}_{2}$ conditions (Table 3 ). The reported concentrations of calciun and magnesium in human body fluids are the order of $1 \mathrm{mM}^{\text {s* }}$ At the concentration of $1 \mathrm{mM} \mathrm{CaCl} \mathrm{C}_{2}$ and $1 \mathrm{mM} \mathrm{MgCl}$. both CAMA and CAMA-syn showed good antimicrobial activity with MIC of $2 \mu \mathrm{M}$ against Gram-negative bacteria. Therefore. these peptides can be described as calcium- and magnesiuml-resistant at a physiological environment.

We next checked the hemolysis of the peptide against mammalian cells by measuring their ability to cause lysis of human erythrocytes. Dose-response curves for the hemolytic activity of the peptides are shown in Figure 1. The CAMA was hemolytic and lysed red blood cells at $50 \mu \mathrm{M}$, whereas CAMAsyn showed no hemolytic activity even at $100 \mu \mathrm{M}$. Both peptides were not cytotoxic against red blood cell at their MIC.

The toxicity of the peptides against mouse RAW264.7 macrophage cells was measured. Effects on cell growth which were assessed by measuring the mitochondrial conversion of MTT to a colored formazan product. are shown in Figure 2.

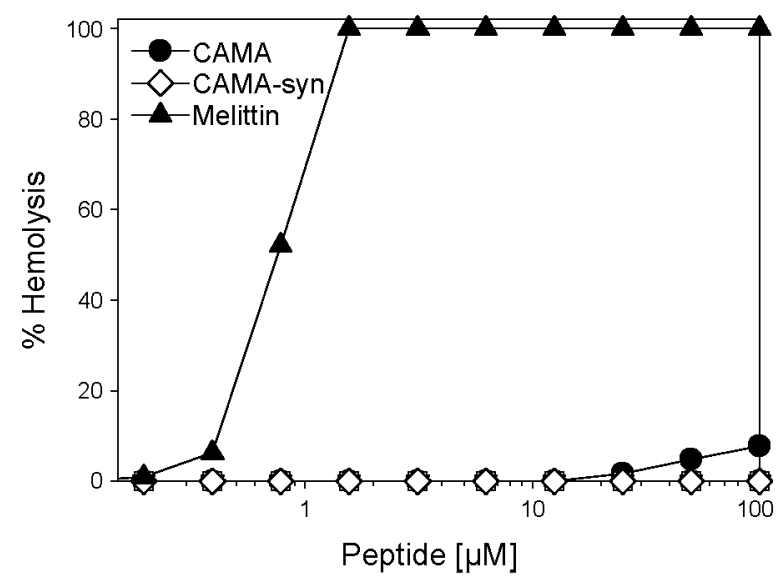

Figure 1. Dose-response of the hemolytic activity of the peptides toward human erythrocytes. 


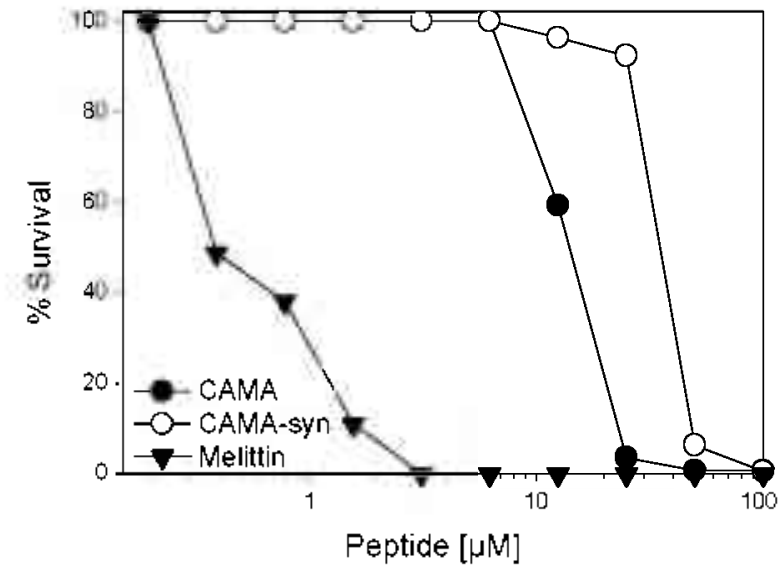

Figure 2. Growth inhibition dose-response curve tor the peptides against RAW264.7 cells. Peptides are indicated as follows: CAMA (•), CAMA-syn (0).
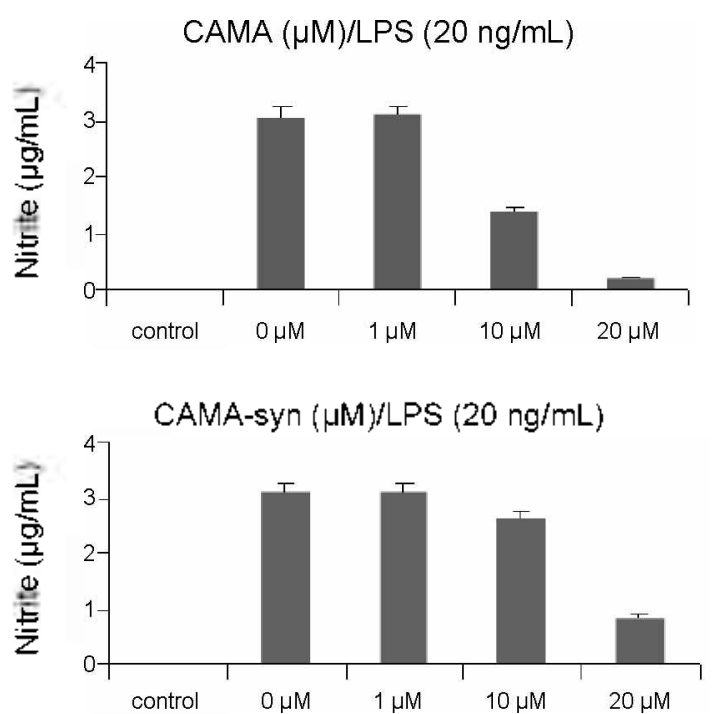

Figure 3. Inhibition of nitrite production by CAMA and CAMAsyn in LPS-stimulated RAW264.7 cells. RAW264.7 cells wete treated with each peptide $(1,10,20 \mu \mathrm{g} / 112 \mathrm{~L})$ in the presence of LPS $(20 \mathrm{ng} / 112 \mathrm{~L})$ for 24 hours. Enor bars represent standard deviations of the mean values determined from three independent experiments.

CAMA showed cytotoxicity against RAW26+.7 cells at low concentration $(10 \mu \mathrm{M})$ while CAMA-syn showed an $90 \%$ survival rate at $25 \mu \mathrm{M}$. Therefore. increase of cationicity in CAMA-syn effectively decreases cy totoxicity of CAMA.

To assess the potential anti-inflammatory activity of CAMA and CAMA-syn. we indirectly measured peptide inlibition of NO production in LPS-simulated RAW264.7 macrophages. by quantifying nitrite concentration. As shown in Figure 3. CAMA and CAMA-syn significantly inhibited NO production by LPS-simulated RAW264.7 macrophage at 10 $20 \mu \mathrm{M}$. Even though CAMA showed a little higher anti-inflammatory activity compared to CAMA-syn, CAMA also displayed significant cy totoxicity against RAW264. 7 cells at $20 \mu \mathrm{M}$. Notably. the inhibitory activity of CAMA-syn against NO production was remarkably potent and CAMA-syn was not cytotoxic
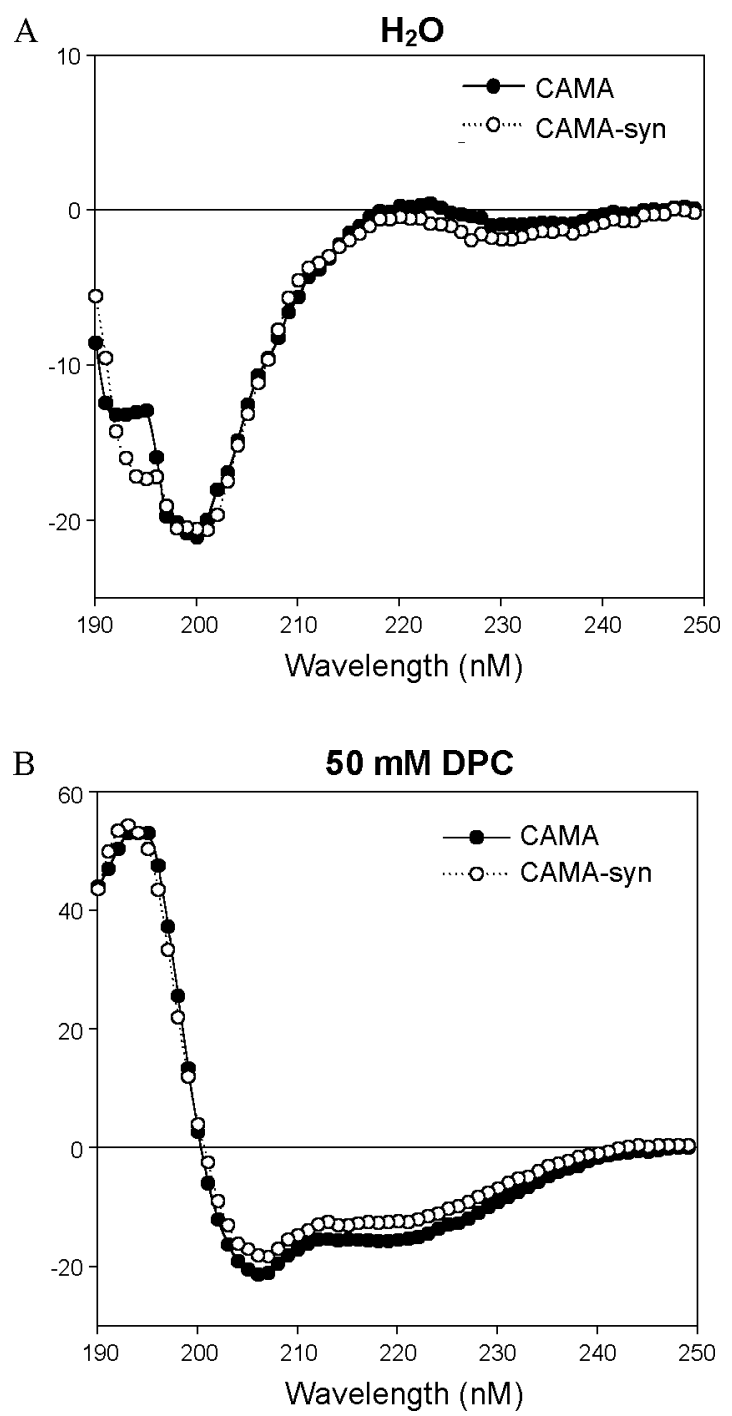

Figure 4. CD spectra of CAMA and CAMA-syn in water (A) and in $50 \mathrm{mM}$ DPC micelles (B).
(A) CAMA

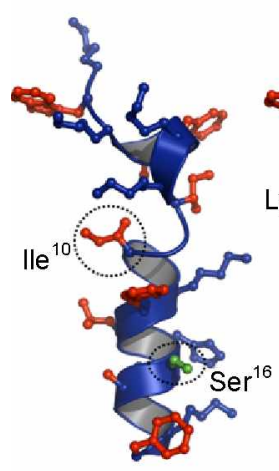

(B) CAMA-syn
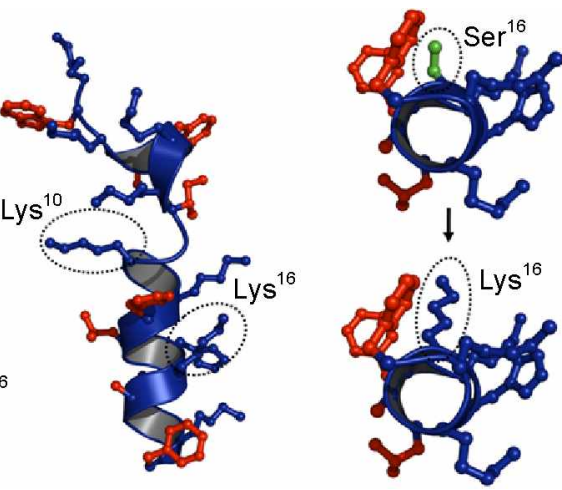

CAMA-syn
Figure 5. Ribbon diagram of CAMA (A) and CAMA-syn (B). Structure of CAMA-Syn was predicted based on the structure of CAMA. Head-on view of CAMA and CAMA-syn (C). The hydrophobic and hydrophilic side-chains are indicated in red and blue, respectively. Ser ${ }^{10}$ are indicated in green for CAMA. 
Table 4. Synergistic effect of the peptides with antimicrobial compounds against $E$. faecalis and VREF

\begin{tabular}{|c|c|c|c|c|c|c|c|c|c|c|}
\hline \multirow{4}{*}{ compound } & \multicolumn{10}{|c|}{$\mathrm{M} C(\mu \mathrm{g} / \mathrm{mL})$} \\
\hline & \multicolumn{5}{|c|}{ E. faecalis } & \multicolumn{5}{|c|}{ VREF } \\
\hline & \multirow{2}{*}{ alone } & \multicolumn{2}{|c|}{ with CAMA } & \multirow{2}{*}{$\begin{array}{r}\text { with } \\
1 / 8\end{array}$} & \multirow{2}{*}{$\frac{\text { CAMA-syn }}{1 / 4}$} & \multirow{2}{*}{ alone } & \multicolumn{2}{|c|}{ with CAMA } & \multicolumn{2}{|c|}{ with CAMA-syn } \\
\hline & & $1 / 8^{a}$ & $1 / 4$ & & & & $1 / 8$ & $1 / 4$ & $1 / 8$ & $1 / 4$ \\
\hline Naringenin & 256 & 256 & 128 & 256 & 128 & 512 & 512 & 256 & 512 & 256 \\
\hline 3,6 -dihydrosy flavone & 64 & 32 & 16 & 32 & 16 & 128 & 64 & 32 & 64 & 32 \\
\hline YKAs3001 & 256 & 128 & 64 & 128 & 64 & 512 & 256 & 128 & 256 & 128 \\
\hline
\end{tabular}

"All synergistic effects are determined in combination with amount of $1: 8$ or $1: 4$ of the peptide MIC.

Table 5. The values of FIC index for the combination of peptide and antimicrobial compound

\begin{tabular}{|c|c|c|c|c|c|c|}
\hline \multirow{3}{*}{ peptide } & \multicolumn{6}{|c|}{ FIC index ${ }^{a}$} \\
\hline & \multicolumn{3}{|c|}{ E. faecalis } & \multicolumn{3}{|c|}{ VREF } \\
\hline & Naringenin & 3,6-dilydroxy flavone & YKAs3001 & Naringenin & 3,6-dihydroxy flavone & YKAs3001 \\
\hline CAMA & 1 & 0.5 & 0.5 & 1 & 0.5 & 0.5 \\
\hline CAMA-Syn & 1 & 0.5 & 0.5 & 1 & 0.5 & 0.5 \\
\hline
\end{tabular}

"The FIC index was determined in the presence of a constant anount of peptide, equal to one-quarter of the peptide MIC

against RAW264. 7 cells at $20 \mu \mathrm{M}$.

We investigated the secondary structures of peptides in aqueous buffer and DPC micelle which is a membrane-like environment by analyzing their $\mathrm{CD}$ as shown in Figure 4. Peptides had random structures in aqueous solution while they showed conformational changes and formed $\alpha$-helical conformations in DPC micelles. As shown in CD spectra. CAMA-syn had very similar stnicture to CAMA in $50 \mathrm{mM}$ DPC micelle. Therefore. we utilized our previous structure of CAMA as determined by NMR spectroscopy to predict the structure of CAMA-syn as shown in Figure $5 .^{2}$ The tertiary structures of both of CAMA has a short amphiphilic helix in the N-terminus and about three turns of $\alpha$-helix in the $C$ terminus, with the flexible hinge region in between in DPC micelle. Figure 5 shows the orientation of the hydrophobic and hyddrophilic side chains of the C-terminal helix of CAMA and CAMA-syn. It is well known that when an amplipathic peptide forms an ion channel the hydrophilic residues face inward to contact the solvent and the hydrophobic side chains face toward the acyl chains of the hydrophobic lipid. The hydrophobic side chains in these peptides. which are colored red. protrude toward one side. and the hydrophilic side chains. which are colored blue. protnide toward the other side. In CAMA-syn. Ile located in the middle of the hinge sequence of CAMA was substituted with Ly's and Ser ${ }^{16}$ (green) as substituted with Lys. resulting in increase of cationicity as shown in Figure 5. We have reported that the partial insertion of the Trp2 of CAMA into the membrane. as well as the electrostatic interactions between the positively charged Lys residues at the $\mathrm{N}$-terminus of the CAMA and the anionic phospholipid head groups. achieve the primary binding to the cell membrane. Then the flexibility or bending potential induced by the GlyIle-Gly hinge sequence in the central part of the peptides may allow the $\alpha$-helix in the $\mathrm{C}$-terminus to span the lipid bilayer. CAMA-syn may have the similar mechanism to CAMA. Furthemore, increase of cationicity in CAMA-syn facilitates the interactions with negatively charged phospholipid of bacterial cell membrane and may increase its bacterial cell selectivity compared to CAMA.

We have previously demonstrated antimicrobial activity of naringenin and YKAs3001 as target of E faecalis and E. coll KAS III. respectively. ${ }^{39.410}$ However. it showed low antimicrobial activity against Gram-positive bacteria even though high binding affinity with KAS III in fluorescence experiments. Also. recent emergence of antibiotic resistance of bacteria has become a serious problem in human medicine throughout the world ${ }^{41-45}$ The main reason for this low antimicrobial activity and bacterial resistance is thought to be low membrane permeability of antimicrobial agents. We examined the sy nergistic effects of CAMA and CAMA-syn to aid membrane permeability of antimicrobial natural compounds such as flavonoids and the results are listed in Table 4 . One-quarter and one-eighth of the MIC concentration of each peptide against E. faecalis and VREF was tested for combination assay. As shown in Table 5, both CAMA and CAMA-syn exhibited same synergistic effects with 3,6-dihydroxỵflavone and YKAs300l against E. faecalis and VREF in the peptide corresponding to onequarter of MIC value of eacl peptide (FIC index: 0.5. an FIC index of $\leq 0.5$ indicates sylnergy ${ }^{46.45}$ ). These results suggest that the cationic $\alpha$-helical antinicrobial peptide can aid antimicrobial agents to permeate the bacterial membrane. However. narigenin, showed no synergistic effects with any peptide against bacterial cells and it can be proposed that their low antimicrobial activities have no relation with membrane permeability.

\section{Conclusion}

In this study, we attempted to develop peptide antibiotics with increased antinucrobial activity without toxicity by synthesizing hybrid peptide analogue of CAMA. The CAMA-syn with substitutions of Ile ${ }^{(1)}$ and Ser ${ }^{16}$ with Lys in CAMA retaining 
of the structure of CAMA with increase of cationicity showed antimicrobial activity similar with CAMA while this peptide have no hemolytic activity and much lower cy totoxicity against RAW264.7 macrophage cells than CAMA. Also. CAMA and CAMA-syn significantly inhibited NO production by LPSstimulated RAW264.7 macrophage at $10.0 \sim 20.0 \mu \mathrm{M}$. CAMAsy'n displayed salt resistance on antimicrobial activity against Escherichia coli at the physiological concentrations of $\mathrm{CaCl}_{2}$ and $\mathrm{MgCl}_{2}$. Also, combinations of peptides with synthetic compounds. YKAs300I and 3.6-dihydroxyflavone, showed synergistic effect against $E$. faecalis and VREF. This study strengthens our efforts to design novel antimicrobial peptides with potent antibiotic activity and synergistic activity without cytotoxicity.

Acknow ledgments. This work was supported by a grant (20080401-034-017) from Biogreen 21 program. Rural Development Administration, Republic of Korea and by the Korea Research Foundation (KRF-2006-005-J03402). KiWoong Jung is supported, in part. by the second BK21 (MOE).

\section{References}

1. Bevins, C. L.: Zasloft, M. Amu. Rer: Biochem. 1990, 59,395

2. Hancock, R. E.: Rozek, A. FEM S M ficrobiol Lett. 2002, 206. $14 \hat{3}$

3. Boman, H. G. Amm Rev Immmol 1995, 13,61

4. Maloy, W. L.; Kari, U. P. Biopolvers (Pept. Sci.) 1995, 37, 105.

5. Hancock, R. E. Lancet 1997, 349, 418

6. Andren, D.: Rivas, L. Biopolvmers (Pept. Sci.) 1998, 47.415.

7. Ore1, Z; Shai, Y. Biopolymers (Pept. Sci.j 1998, 17, 451

8. Mivasaki, K: Lehrer, R. I. Int. J. Antmicrob. Agents 1998, 9, 269

9. Lelurer, R. I.: Ganz. T. Cumr. Opin. in Immmol 1999, 11, 23

10. Hancock, R. E.; Chapple, D. Antimicrob. Agents Chemother. $1999,43,1317$

11. Mivasaki, K; Lelurer, R. I. Int. J. Antmicrob. Agents 1998, 9 , 269

12. Lelurer, R. I.: Ganz, T. Cumr. Opin. in Inmmol 1999, 11, 23.

13. Zaslotte. M. Proc. Natl Acad Sci. L. S. A. 1987, 81, 5449

14. Steiner, H.: Hultmark, D.: Engstrom, A.; Bennich, H.; Boman, H. G. Kature 1981, 292,246.

15. Lee, I. Y:: Boman, A.; Sun, C.: Andersson, M.: Jonvall, H.: Mutt, V.: Boman, H. G. Proc. Natl Acad Sci. L. S. A. 1989,86,9195.

16. Shin, S. Y.; Lee, M. K.; Kim, K. L.; Halun, K. S. J. Peptide Res. $1997,50,279$

17. Shin, S. Y.: Kang, J. H.: Lee, M. K.: Kin, S. Y.; Kim, Y.; Halm, K. S. Biochem. Mol Biol. Int 1998, H, 1119

18. Shin, S. Y.; Kang, T. H.: Halum. K. S. J. Peptide Res. 1999, $53,82$.

19. Oh, D: Shin, S. Y.: Kang, I. H.; Hahm, K. S.; Kim, Y. J. Pept. Res. $1999,53,578$.
20. Oh, D.: Shin, S. Y.: Lee, S.: Kang, J. H.: Kim, S. D.: Ryul, P. D.; Hahm, K. S.: Kim, Y. Biochemistry 2000, 39, 11855

21. Shin, S. Y.: Yang, S. T.: Park, E. J.: Eom, S. H.: Song, W. K.; Kim, Y: Halm, K. S.; Kim, J. I. Biochent. Biophys. Res. Contmin. 2002, 290,558.

22. Park. Y.: Park, S. N.: Park, S. C.: Shin, S. O.: Kim, J. Y.; Kang, S. J.: Kim, M. H., Jeong. C. Y.: Hahm, K. S. Biochim. Biophns. Acta $2006,176+24$

23. Giacometti, A.; Cirioni, O.; Barchiesi, F.; Fortuna, M.; Scalise, G. J. Antimicrob. Chemother 1999, 44,642 .

24. Giacometti, A.: Cirioni, O.: Del Prete, M. S.: Paggi, A. M.; D'Errico, M. M.; Scalise, G. J. Antimicrob. Agents Chentother: $2000,21,1155$

25. Graham, S.; Coote, P. I. J. Antimicrob. Chemother. 2007, 59. 759

26. Yeo, I. Y: Koo, B. K.: Oh, E. S.; Han, I. O.; Lee, W. Bull Korean Chem. Soc. 2008, 29, 1013

27. Woo, S.; Kang, D. H.; Kim, J.; Lee, C. S.; Lee, E. S.; Tahng, Y; Kwon. Y.: Na. Y. Bull. Korean Chem. Soc. 2008. 29.471.

28. Scudiero, D. A.; Shoemaker, R. H.; Paull, K. D.: Monks. A.; Tiemey, S.; Nofziger, T. H.; Currens, M. J.; Seniff, D.; Boyd, M. R. Concer Res. 1988, 48, 482733

29. Green, L. C.: Wagner, D. A.: Glogowski, J.; Skipper, P. L:; Wishnok. J. S.: Tannenbaum. S. R. Anal Biochem 1982, 126.131.

30. Jeong, K. W.; Lee, J. Y.; Kim, Y. Bull. Korean Chem. Soc. 2007. 28,1335

31. Klastersky, T.; Cappel, R; Daneau, D. Antimicrob. Agents Chemother 1972, 2, 470

32. Eliopoulos, G. M.: Moellering, R. C. Antimicrobial Combinations; Williams and Wilkins: Baltimore, MD, 1996; pp 432-492.

33. White, R. L.; Burgess, D. S.; Manduru, M. Bosso, J. A. Antimicrob. Agents Chemother: 1996, 40,1914

34. Lee, S. A.; Kim, Y. K.; Lim, S. S.; Zhu, L. W.; Ko, H.: Shin, S. Y.: Hahm, K. S.; Kim, Y. Biochemistrv 2007, 46, 3653

35. Hopp, T. P: Woods, K. R. Proc. Natl Acad. Sci. L. S. A. 1981, 78,3824

36. Goldman, M. J: Anderson, G. M.: Stolzenberg, E. D.; Kari, D P.: Zasloff, M. K.; Wilson. J. M. Cell 1997, 88, 553

37. Piers, K. L.; Brown, M. H.; Hancock, R. E. W. Antimicrob. Agents Chenther. 1994, 38, 2311 .

38. Cole, A. M.; Darouiche, R. O.; Legarda, D.: Connell, N.; Diamond, G. Antimicrob. Agents Chemother 1987, 4t, 2039.

39. Jeong, K. W.; Lee, J. Y.; Kang, D. I.; Lee, J. U.; Shim, S. Y; Kim, Y. J. Nat Prod $\mathbf{2 0 0 9}, 72,719$.

40. Lee, J. Y.: Ieong, K. W.: Lee, I. U.: Kang, D. I.: Kim, Y. Bioong. 1/ed. Chem 2009, 17, 1506

41. George, A. M. FEl IS M fichobiol. Lent. 1996, 139, 1

42. Hancock. R. E. W. Clin. Infect. Dis. 1998, 27, S93.

43. Noskin, G. A. J. Lab. Clin. Med. 1997, 130, 14.

44. Rice. L. B. Emerg. Infect. Dis. 2001. 7. 183.

45. Linden, P. K. Miller, C. B. Diagn. Mficrobiol Infect. Dis. 1999. 33,113

46. Odds, F. C. J. Antinticrob. Chentother 2003, $52,1$.

47. Pas. U.; Oedenkoven, M.; Papo, N.; Oren, Z.: Shai, Y.; Sahl, H. G. J. Antimicrob. Chemother 2004. 53.230 